\title{
Maraş Biberi Üretim Memnuniyetinin Yapısal Eşitlik Modeli ile Belirlenmesi
}

\author{
Yeşim AYTOP 1 \& , Cuma AKBAY2 id \\ ${ }^{1}$ Kahramanmaraş Sütçü İmam Üniversitesi, Pazarcık MYO, Dış Ticaret Bölümü, Kahramanmaraş, Türkiye \\ ${ }^{2}$ Kahramanmaraş Sütçü İmam Üniversitesi, Ziraat Fakültesi, Tarım Ekonomisi Bölümü, Kahramanmaraş, Türkiye
}

\section{ÖZET}

Son yıllarda Maraş Biberi ekim alanlarının artması üreticilerin bu ürüne yöneldiğini göstermektedir. Üretimi ile tarım sektörü ve tarıma dayalı sanayi sektörüne önemli katkısı bulunan Maraş Biberi’nin, üretim ve pazarlanmasında kullanılan işgücü ile bölge ve ülkedeki tarımsal istihdama katkısı oldukça yüksektir. Maraş Biberi üretiminin tercih edilme nedenlerinin belirlenmesi önem arz eden konulardan biridir. Bu çalışmanın temel amacı, Maraş Biberi üretiminin tercih edilmesinde etkili olan faktörleri belirleyerek üretimden memnuniyet düzeylerini tespit etmektir. Araştırmanın ana materyalini; Türkiye'deki Maraş Biberi üretimini temsil etmesi bakımından Gaziantep, Kahramanmaraş ve Kilis illerinde 156 Maraş Biberi üreticisi ile yüz yüze yapılan anketlerden elde edilen veriler oluşturmaktadır. Verilerin analizinde tanımlayıcı istatistikler, doğrulayıcı faktör analizi ve yol analizinden yararlanılmıştır. Yapısal Eşitlik Modeli sonucuna göre, Maraş Biberi üretim memnuniyetinde; ekonomik faktörlerin, üretim öngörüsünün ve pazarlama faktörlerinin doğrudan etkisi olduğu tespit edilmiştir. Ekonomik faktörler gizil değişkenindeki bir birimlik artışın Maraş Biberi üretim memnuniyetini 0.64'lük bir artışla, üretim öngörüsü gizil değişkenindeki bir birimlik artışın Maraş Biberi üretim memnuniyetini 0.32'lik bir artışla, pazarlama faktörleri gizil değişkenindeki bir birimlik artışın üretim memnuniyetini 0.20'lik bir artışla etkileyeceği tespit edilmiştir.
DOI:10.18016/ksudobil.402182

\author{
Makale Tarihçesi \\ Geliş Tarihi : 07.03.2018
}

Kabul Tarihi : 16.04.2018

\author{
Anahtar Kelimeler \\ Yapısal Eşitlik Modeli, \\ Path Analizi, \\ Doğrulayıcı Faktör Analizi, \\ Üretici Memnuniyeti
}

Araştırma Makalesi

\section{Determination of Maraş Pepper Production Satisfaction with Structural Equation Model}

\section{ABSTRACT}

In recent years, the increase of Maras Pepper cultivation area indicates that there is a trend towards this product by the producers. Maraş Pepper, which has significant contribution to the agricultural sector and the industry based on agriculture, has a very high labor force in production and marketing, and the agricultural employment contribution in the region and country is high. Determination of reasons for preferring Maraş Pepper is one of the most important issues. The main purpose of this study is to determine the levels of satisfaction from production by determining the factors that are effective in Maraş Pepper production. The main material of the study; in order to represent the production of Maras Pepper in Turkey; constitutes of data obtained from face-to-face surveys with 156 Maraş Pepper producers in Gaziantep, Kahramanmaraş and Kilis provinces. Descriptive statistics, confirmatory factor analysis and path analysis were used for the obtained data analyses. According to the result of Structural Equation Model economic factors, production forecast and marketing factors were found to be directly influential on Maraş Pepper production satisfaction. It was determined that a unit increase in the economic factors latent variable would increase Maraş Pepper production satisfaction by 0.64, a unit increase in the personal factors latent variable would increase Maraş Pepper production by 0.32 and a unit increase in the

\section{Article History}

Received : 07.03.2018

Accepted : 16.04.2018

\section{Keywords \\ Structural Equation Model, \\ Path Analysis, \\ Confirmatory Factor Analysis, Farmer satisfaction}

\section{Research Article}


marketing factors latent variable would increase Maraş Pepper production by 0.20 .

To Cite : Aytop Y, Akbay C 2018. Maraş Biberi Üretim Memnuniyetinin Yapısal Eşitlik Modeli ile Belirlenmesi. KSÜ Tarım ve Doğa Derg 21(5): 725-737. DOI:10.18016/ksudobil.402182

\section{GİRIŞ}

Üretimi ile tarım sektörü ve tarıma dayalı sanayi sektörüne önemli katkısı bulunan Maraş Biberi'nin, üretim ve pazarlanmasında kullanılan işgücü ile bölge ve ülkedeki tarımsal istihdama katkısı oldukça yüksektir. Bunun yanı sıra ihraç edilen ve ihraç potansiyeli olan bir ürün olması Maraş Biberi üretiminin önemli bir tarımsal faaliyet olduğunu, tarımsal sürdürülebilirlik açısından üzerinde durulması ve üretiminin desteklenmesi gerekliliğini ortaya koymaktadır.

Dünya pul ve toz biber üretimi 2013 yılı verilerine göre 3.5 milyon tondur. En fazla üretimin yapıldığ 5 ülke sirasıyla Hindistan (1.4 milyon ton), Çin (300 bin ton), Peru (164 bin ton), Tayland (156 bin ton) ve Pakistan'dır (150 bin ton). Hindistan tek başına toplam üretimin \%39.7'sini karşllarken diğer üretimin yoğun olduğu Çin, Peru, Tayland ve Pakistan toplam üretimin \%22.2'sini karşlamaktadır. Türkiye, 16 bin ton üretim ile dünya üretimin $\% 0.05$ 'ini karşılamaktadır. Dünya kuru kırmızıbiber ihracatı 581.4 bin tondur. Hindistan, toplam ihracatın \%50'sini karşılamaktadır. Dünya kuru kırmızıbiber ithalatı ise 563.8 bin tondur. Ithalatın \%20.4'ü ABD'ye yapılmaktadır. Türkiye'nin toplam ihracattaki payı ise yaklaşık 1139 ton ile \%0.02'dir (FAO, 2013).

Baharatlık işlenmemiş kırmızıbiber Türkiye'de 122415 da alanda, 228531 ton üretilmektedir. Yaygın olarak ülkenin güneyinde üretilen baharatlık kırmızıbiber sırasıyla en çok Şanlıurfa, Gaziantep, Kahramanmaraş ve Kilis illerinde üretilmektedir. Ekili alanın \%43.37'sini karşllayan Şanlıurfa ili, toplam üretimin de \%53'ünü karşllamaktadır. Gaziantep, Kahramanmaraş ve Kilis illeri toplam baharatlık kırmızıbiber ekili alanın \%48.80'ini karşılarken, üretimin de \%37.43'ünü karşlamaktadır (TÜİK, 2016).

Maraş Biberi için 26.11.2001 tarihinde Kahramanmaraş Ticaret Borsası tarafından coğrafi işaret tescili için başvurulmuştur. 14.04.2002 tarihinde Maraş Biberi coğrafi işaret tescili almıştır. Coğrafi işaret için yerel imalatçılar Kahramanmaraş Ticaret ve Sanayi Odası'na başvuru yapmaktadırlar. Coğrafi işaretin amacına uygun ve iyi niyetli olarak kullanılacağına dair iki taraflı protokol imzalayarak coğrafi işareti ambalajlarında kullanabilmektedirler. Türkiye'de 555 saylı Kanun Hükmünde Kararname'ye göre coğrafi işaret; 'belirgin bir niteliği, ün ya da diğer özellikleri itibariyle kökenin bulunduğu bir yöre, alan, bölge veya ülke ile özdeşlemiş bir ürünü gösteren işaretlerdir'. Coğrafi işaretler, menşe ve mahreç işareti olmak üzere ikiye ayrılmıştır. Maraş Biberi, menşe işareti almış coğrafi işaretli bir üründür (TPE, 2002).

Bir ürünün menşe adını taşıması için,

- "Coğrafi sınırları belirlenmiş bir yöre, alan, bölge ya da çok özel durumlarda ülkeden kaynaklanan bir ürün olması",

- "Tüm özelliklerini veya esas niteliğini veya özeliklerinin bu yöre, alan veya bölgeye özgü coğrafi unsurlardan kaynaklanan bir ürün olması",

- "Üretimi, işlenmesi ve diğer tüm işlemlerinin tamamıla bu yöre, alan veya bölge sinırları içinde yapılan bir ürün olması gerekmektedir".

Kahramanmaraş, Adıyaman, Gaziantep, Kilis, Hatay, Şanlıurfa illerinde üretilen toz, pul ve isot yapımında kullanılan Maraş Biberi'nin meyveleri konik şekilli, uç kısmı sivri ya da küt olabilmektedir (TPE, 2002).

Tarımsal üretimde herhangi bir üründe sürdürülebilirliğin sağlanması üreticinin o üründen elde ettiği kar ile birlikte birçok faktöre bağlıdır. Bu faktörler ekonomik, çevresel, fiziksel, kişisel, pazarlama ve politik faktörler olarak sıralanabilir. Bu araştırmada üreticilerin Maraş Biberi üretiminden memnuniyet düzeyleri yapısal eşitlik modelinden (YEM) yararlanılarak belirlenmeye çalışılmıştır. İlk olarak sosyal bilimlerde özellikle psikoloji ve sosyoloji alanlarında kullanılan YEM, eğitim, pazarlama ve tıp gibi çeşitli disiplinlerde de kullanılmaya başlanmıştır. Geleneksel regresyon modellerinde açıklayıcı değişkenlerdeki olası ölçüm hataları göz ardı edilmekte, sonuçlar yanlış ve yanıltıcı sonuçlar vermektedir. Geleneksel regresyon modellerinin aksine YEM, bir modeldeki gözlenen (hem bağıml, hem bağımsız) değişkenlere ilişkin ölçüm hatalarını açıç̧a hesaba katan bir yöntemdir (Bayram, 2013). YEM'in günümüzde oldukça yaygın bir şekilde kullanılmasının sebebi gözlenebilen ve gözlenemeyen değişkenler arasındaki doğrudan ve dolaylı ilişkileri tek bir model içerinde test edebilme özelliğidir. YEM, aynı anda birden fazla regresyon analizi yapabilmektedir (Meydan ve Şeşen, 2011).

Yapısal eşitlik modellemesi çerçevesinde gizil değişkenleri kullanarak yapılan çok sayıda çalışma mevcut olmasına karşın tarım alanında üretici memnuniyeti ile yapılmış çalışmalar çok kısıtlıdır (Pennings ve Leuthold, 2000; Şahin ve ark., 2008; Yllmaz ve ark., 2009; Kayacan ve Gültekin, 2012; Okur Berberoğlu ve Uygun, 2012).

Üreticilerin Maraş Biberi üretimini tercih etmesinin altında yatan nedenlerin tespit edilmemiş olması ve 
son on yılda Maraş Biberi ekili alandaki artışın altında yatan nedenlerin detaylı incelenmesinin gerekliliği araştırmanın önemini ortaya koymaktadır. Son yıllarda Maraş Biberi ekim alanının artması üreticilerin kırmızıbiber üretimine yöneldiğini göstermektedir. Bu sonuca paralel olarak üreticilerin Maraş Biberi üretimini tercih nedenleri ortaya konmaya çalışacaktır. Bu araştırmanın temel amacı ekonomik, çevresel ve fiziksel, kişisel faktörler bakımından Maraş Biberi üretim memnuniyetinin belirlenmesidir.

\section{MATERYAL ve YÖNTEM}

\section{Materyal}

$\mathrm{Bu}$ çalışmanın ana materyalini, Maraş Biberi üreticileri ile yüz yüze yapılan anketlerden elde edilen veriler oluşturmaktadır. Araştırmanın Türkiye'yi temsil etmesi bakımından anketler Maraş Biberi üretiminin \%87'sini karşılayan 3 ilde yapılmıştır İlleri temsil etmesi bakımından Maraş Biberi ekili alanın en fazla olduğu dolayısıyla üretimin en fazla olduğu ilçeler seçilmiştir. Görüşülecek çiftçilerin örnek hacminin belirlenmesinde oransal örnek hacmi formülü kullanılmıştır (Newbold, 1995).

Araştırma kapsamına alınan illerdeki Maraş Biberi üreten işletme sayısı 2529'dur. (Anonim, 2016). Buna göre, \%99 güven aralığı ve \%10 hata payı için örnek hacmi 156 olarak hesaplanmıştır.

$$
\begin{gathered}
n=\frac{N p(1-p)}{(N-1) \sigma_{\hat{p}_{x}}^{2}+p(1-p)} \\
\sigma_{p_{x}}^{2}: \text { Oranın Varyansı } \\
\mathrm{n} \quad: \text { Örnek hacmi } \\
\mathrm{N} \quad: \text { Anakitle }
\end{gathered}
$$

p :Baharatlık kırmızıbiber üreticilerin oranı (maksimum örnek hacmine ulaşmak amacıyla $\mathrm{p}=0.5$ alınmıştır. $)$

Araştırma kapsamına alınan ilçeler Çizelge 1'de belirtilmiştir. Anketler 2016 yılı Kasım ve Aralık aylarında 3 ilde, 7 ilçede, toplamda 156 üretici ile görüşülerek gerçekleştirilmiştir. Illlerde yapılan anket sayısı ildeki üretici sayılarına göre oransal olarak dağıtılmıştır. Gıda, Tarım ve Hayvancılık Bakanlığg İlçe Müdürlüklerinden alınan bilgiler ile Maraş Biberi üretiminin yoğun olarak yapıldığ mahalleler

\begin{tabular}{|c|c|c|c|}
\hline İl Adr & İlçe Adı & Üretici sayısı & Yapılan anket sayısı \\
\hline \multirow{2}{*}{ Gaziantep } & Islahiye & 523 & 35 \\
\hline & Nurdağ & 336 & 22 \\
\hline \multirow{3}{*}{ Kahramanmaraş } & Pazarcık & 159 & 11 \\
\hline & Türkoğlu & 158 & 10 \\
\hline & Dulkadiroğlu & 77 & 5 \\
\hline \multirow{2}{*}{ Kilis } & Merkez & 667 & 45 \\
\hline & Musabeyli & 415 & 28 \\
\hline Toplam & & 2335 & 156 \\
\hline
\end{tabular}
belirlenerek toplamda 26 mahallede anket çalışması yürütülmüştür.

Çizelge 1. Yapılan anket sayısının dağılımı

Kaynak: Anonim, 2016

\section{Verilerin analizinde kullanılan yöntemler}

Verilerin analizinde tanımlayıcı istatistikler, ANOVA testi ve Doğrulayıcı Faktör Analizi ve Yol (Path) Analizi'nden yararlanılmıştır.

\section{Yapısal Eşitlik Modeli (YEM)}

Bazı yazarlar YEM'i nedensel modelleme, nedensel analiz, eş zamanlı yapısal modelleme, kovaryans yapı analizi, yol analizi ve doğrulayıcı faktör analizi olarak isimlendirmekte (Tabachnick ve Fidell, 2001), fakat uygulamada yol analizi ve doğrulayıcı faktör analizi YEM'in özel uygulama tipleridir (Meydan ve Şeşen, 2011).

YEM, bazı özellikleri bakımından klasik çok değişkenli istatistiksel yöntemlerden farklllık göstermektedir.

- Keşfedici bir yaklaşım yerine, doğrulayıcı bir yaklaşım benimsemektedir (Diğer yöntemler veri seti üzerindeki ilişkileri keşfetmeye çalışırken; YEM, kuramsal olarak oluşturulmuş bir ilişkinin veri ile uyumunu doğrulamaktadır. YEM'in hipotez testleri için diğer yöntemlerden daha başarılı olduğu söylenebilir.

- Geleneksel yöntemler ölçüm hatalarını ayrı ayrı ele alırken, YEM tüm çözümlemelerde ölçüm hatalarını açıkça hesaba katmaktadır.

- Geleneksel yöntemler analizlerde sadece gözlenebilen değişkenleri dikkate alırken, YEM aynı model içerisinde hem gözlenebilen hem gözlenemeyen değişkenlerin aynı anda test edilebildiği, doğrudan ve dolaylı ilişkilerin ölçülebildiği, bir model olduğundan günümüzde oldukça yaygın olarak kullanılmaktadır (Byrne, 2010; Meydan ve Şeşen, 2011).

\section{Doğrulayıcı Faktör Analizi (DFA)}

Doğrulayıcı faktör analizi yapısal eşitlik modeli 
analizinin sunmuş olduğu tekniklerden biridir. Daha önce yapılmış olan uygulamalı araştırmalar ile tespit edilen ve teoriye dayalı olarak geliştirilen kavramsal yapıları ölçmede kullanılan ölçeklerin geçerlilik ve güvenilirlik düzeyini belirlemeye olanak sağlayan bir yöntemdir (MacCallum ve Austin, 2000; Terblanche ve Boshoff, 2006; Avcılar ve Varinli, 2013).

Doğrulayıcı faktör analizi ile ölçüm modelinde yer alan içsel ve dışsal boyutların yapı geçerliliğinden söz edebilmek için,

- Kavramsal yapıyı oluşturan her boyutun tek boyutlu olması,

- Boyutlara ilişkin yakınsama geçerliliği, boyutlara ilişkin ayrışma geçerliliği,

- Boyutlara ilişkin güvenilirlik düzeyi,

- Boyutların tahmin geçerliliği kriterlerini karşılaması gerekmektedir (Churchill, 1979; Bagozzi, 1981; Gerbing ve Anderson, 1988; Avcular ve Varinli, 2013).

Doğrulayıcı faktör analizi günümüzde en geçerli faktör analizi tekniklerinden biridir. Son yıllarda yurtdışında yapılan ölçek uyarlama çalışmalarında sıklıkla başvurulan bir teknik olmakla birlikte genel kanı ölçek uyarlama çalışmalarında mutlaka başvurulması gereken bir analiz yöntemidir (Seçer, 2013).

Doğrulayıcı faktör analizinde dört farklı model test edilebilir. Bunlar, tek faktörlü model, birinci düzey çok faktörlü model, ikinci düzey çok faktörlü model ve ilişkisiz modellerdir (Byrne, 1998; Sümer, 2000; Meydan ve Şeşen, 2011).

$\mathrm{Bu}$ çalışmada doğrulayıc faktör analizinde ikinci düzey çok faktörlü model test edilmiştir. Gözlenen değişkenlerin birden fazla birbiriyle bağlantısız faktör altında toplandığı daha sonra ise bu faktörlerin daha geniş ve kapsayıcı bir faktör altında birleştiği model ikinci düzey çok faktörlü model olarak tanımlanmıştır. Modelde gözlenebilen değişkenler birden fazla bağımsız boyut altında toplanır. Daha sonra bu faktörler daha kapsayıc bir model altında bir araya gelir. Bazı ölçekler yapıları gereği birinci düzey çok faktörlü iken bazı ölçekler ikinci düzey çok faktörlü olabilmektedir. $\mathrm{Bu}$ nedenle doğrulayıcı faktör analizi uygulanırken mutlaka çok boyutlu ölçeklerin ikinci düzey çok faktörlü modellerinin de test edilmesi gerekmektedir (Meydan ve Şeşen, 2011).

\section{Yol Analizi (Path Analizi)}

Çoklu regresyon ile yakından ilişkisi olan Path analizi, iki veya daha çok değişken arasındaki nedensel ilişkilerin test edilmesinde, doğrudan ve doğrudan olmayan ilişkilerin karşılaştırılmasında kullanılır. Yol analizi, gözlenen ve gizil değişkenlerle olmak üzere iki şekilde uygulanabilir. YEM'de yol analizinin amacı, YEM'in gizil değişken model kısmını test etmektir. Yol analizi çoklu regresyon analizine çok benzemekle birlikte onu üstün kılan bazı özellikleri vardır:
- Çoklu regresyon analizinde sadece bir bağıml değişken var iken YEM'de birden fazla bağımsız değişken aynı anda tanımlanabilmektedir.

- Çoklu regresyonda bağımlı ve bağımsız değişkenlerin rol değiştirmesi mümkün değil iken YEM'de değiş̧kenler aynı anda bağımlı ya da bağımsız olarak tanımlanabilir.

Path analizi, karmaşı ve fazla sayıda değişkenin bağıml ve bağımsız konumuna geçtiği problemlerin çözümünde regresyona göre daha doğru, etkin ve kolay bir yaklaşım tekniğidir (Schumacker ve Lomax, 1996; Meydan ve Şeşen, 2011). Yol analizlerinde değişkenlerin birbirleri üzerine etkilerini göstermek amaciyla resimler göstergeler yer alır. Path analizinde, gözlenen değişkenlerle ve gizil değişkenlerle yol analizi olmak üzere iki yöntem kullanılmaktadır.

$\mathrm{Bu}$ çalışmada gizil değişkenlerle yol analizi metodundan yararlanılmıştır.

Gizil değişkenlerle yol analizi, gözlenen değişkenlerle yol analizine göre daha güvenilir sonuçlar verir. Her bir gizil değişkenin oluşturulan ölçme modelleri (doğrulayıcı faktör analizi modelleri) ile temsil edilmesi ve modele ölçüm hatalarının da dahil edilebilmesidir (Şimşek, 2007; Meydan ve Şeşen, 2011).

Bu çalışmada YEM ile, üreticilerin Maraş Biberi üretim memnuniyetinin ölçmek amaçlanmıştır.

Üreticilerin Maraş Biberi üretim memnuniyetini belirlemek amacıyla yapısal eşitlik teorisine uygun bir model oluşturulmuştur. Daha önce Maraş Biberi üretim memnuniyetini inceleyen bir çalışma olmadığından, model oluşturulurken benzer konularda yapılan çalışmalardan ve gözlemlerden yararlanılmıştır.

Oluşturulan modelde,

- Ekonomik faktörler

- Çevresel ve fiziksel faktörler

- Kişisel faktörler

- Pazarlama faktörleri

- Maraş Biberi üretim öngörüsü gizil değişkenlerinin Maraş Biberi üretim memnuniyetini etkileyeceği varsayılmıştır (Şekil 1).

Modeldeki belirtilen gizil değişkenlerin üreticilerin Maraş Biberi memnuniyetini etkileyeceği varsayılmıştır. $\mathrm{Bu}$ modelde $(1,2,3,4,5, \ldots)$ gözlenen değişkenleri; ekonomik, çevresel ve fiziksel, kişisel ve pazarlama faktörleri gizil (latent) değişkenleri ve Maraş Biberi üretim öngörüsü endojen gizil değişkeni, Maraş Biberi üretim memnuniyeti ise endojen gözlenen değişkeni ifade etmektedir (Şekil 1).

Her bir gizil değişken 5'li Likert ölçeği ile değerlendirilmiştir.

Üreticilerin Maraş Biberi üretim memnuniyeti ile faktörler arasındaki ilişkinin belirlenmesinde test 
edilecek araştırma hipotezleri aşağıdaki gibidir:

$\mathrm{H}_{1}$ : Ekonomik faktörler Maraş Biberi üretim memnuniyeti üzerinde doğrudan etkilidir.

$\mathrm{H}_{2}$ : Çevresel ve fiziksel faktörler Maraş Biberi üretim memnuniyeti üzerinde doğrudan etkilidir.

$\mathrm{H}_{3}$ : Kişisel faktörler Maraş Biberi üretim memnuniyeti üzerinde doğrudan etkilidir.

$\mathrm{H}_{4}$ : Pazarlama faktörleri Maraş Biberi üretim memnuniyeti üzerinde doğrudan etkilidir.

$\mathrm{H}_{5}$ : Maraş Biberi üretim öngörüsü üretim memnuniyeti üzerinde doğrudan etkilidir.
$\mathrm{H}_{6}$ : Ekonomik faktörler Maraş Biberi üretim öngörüsünde doğrudan etkilidir.

$\mathrm{H}_{7}$ : Çevresel ve fiziksel faktörler Maraş Biberi üretim öngörüsünde üzerinde doğrudan etkilidir.

$\mathrm{H}_{8}$ : Kişisel faktörler Maraş Biberi üretim öngörüsünde doğrudan etkilidir.

$\mathrm{H}_{9}$ : Pazarlama faktörleri Maraş Biberi üretim öngörüsünde doğrudan etkilidir.

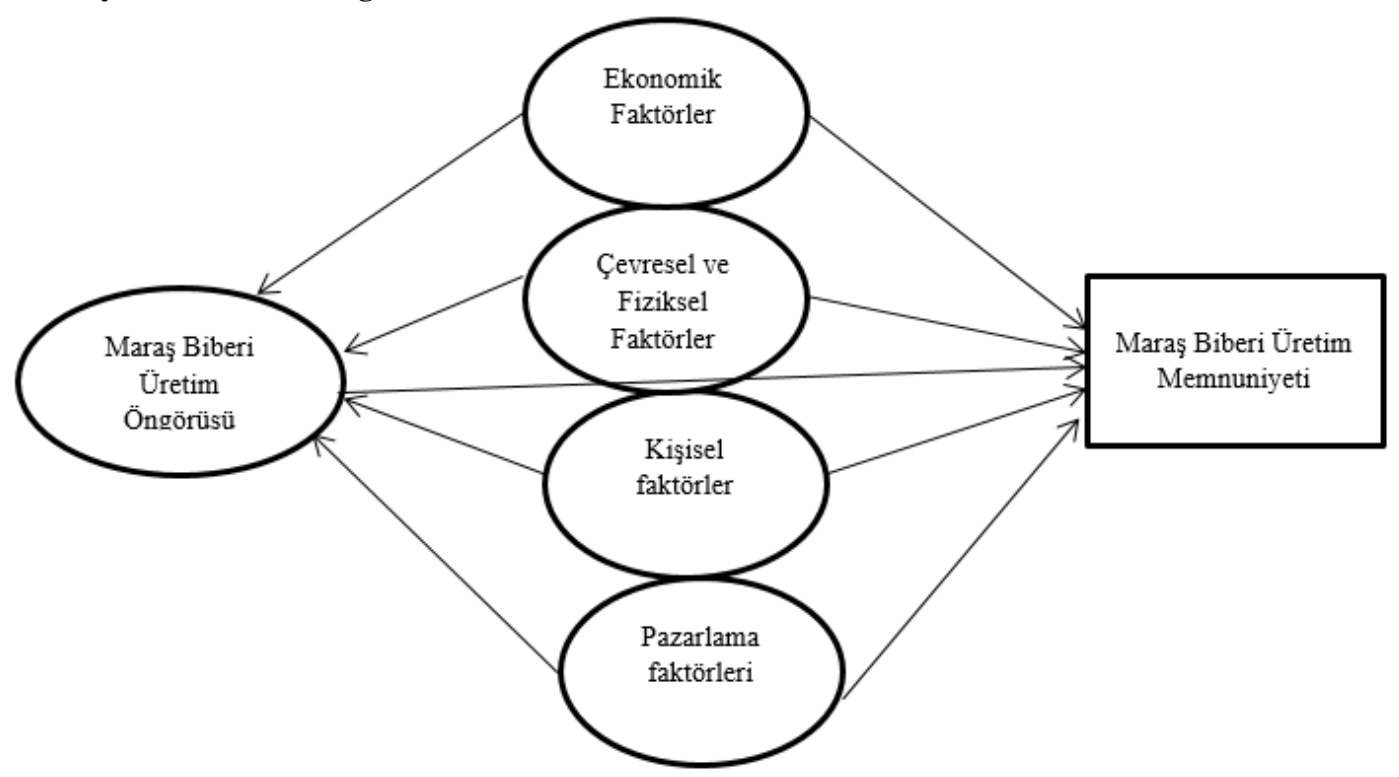

Şekil 1. Üreticilerin Maraş Biberi üretim memnuniyeti için önerilen YEM tasarısı

\section{BULGULAR ve TARTIŞMA}

\section{Üretici ve Arazi Bilgileri}

Anket yapılan bireylerin sosyo-demografik özelliklerini belirlemek amacıyla Çizelge 2 oluşturulmuştur.

Anket yapılan bireylerin tamamı erkek, \%32.05’i 40 yaş ve altında, \%43.59'u 41-55 yaş arasında, yaş ortalaması ise 46.72 yıldır.

Üreticilerin eğitim aldıkları süreler incelendiğinde $\% 63.46$ 'sının 5 yıl ve daha az süre ile eğitim aldığı, \%22.44'ünün 6-8 yıl arasında eğitim aldığı tespit edilmiştir. Alınan eğitim süresi ortalama 6.35 yıldır. Üreticilerin \%50'si 21-40 yıl arasında tarımsal üretim tecrübesine sahiptir (tarımsal üretim tecrübesi ortalama 28.19 yıl). Araştırma sonuçlarına benzer bir şekilde Akbay ve ark. (2012) Kahramanmaraş ve Gaziantep illerinde kırmızıbiber üreticileri ile yaptıkları araştırmalarında üreticilerin yaş ortalamasının 45.3 yıl olduğunu, \%56.3'ünün 5 yıl ve daha az süre eğitim aldığını, \%20.3’ünün 6-8 yıl arasında eğitim aldığını, tarımsal üretim tecrübesinin ise ortalama 27 yıl olduğunu tespit etmişlerdir. Doğu Akdeniz bölgesinde yapılan başka bir araştırma sonucuna göre üreticilerin yaş ortalamasının 44.58 yll olduğu tespit edilmiştir (Boz, 2013).

Üreticilerin aylık hanehalkı gelirleri incelendiğinde, aylık hanehalkı gelirin ortalama 2137.83 TL olduğu, üreticilerin \%48.08'inin 1500-2500 TL arasında gelir elde ettiği, $2500 \mathrm{TL}$ ve üzerinde gelir edenlerin oranının ise \%19.23 olduğu tespit edilmiştir.

Anket yapılan üreticilerin aileleri ile ilgili bilgiler incelendiğinde; \%44.87'sinin hanesinde 1-5 kişi, \%37.18'inin hanesinde 6-7 kişi yaşadığı, hane halkı sayısının ortalama 5.97 kişi, ailede tarımda çalışan kişi sayısının ise ortalama 2.62 kişi olduğu tespit edilmiştir. Kahramanmaraş ve Gaziantep illerinde yapılmış benzer bir araştırmada ortalama hanehalkı sayısı 6 kişi, ailede tarımda çalışan kişi sayısı ise ortalama 2.9 bulunmuştur (Akbay ve ark., 2012).

Anket yapılan üreticiler, ortalama 40.88 da alanda Maraş Biberi üretimi yapmaktadırlar (Çizelge 3). İşlenen arazinin \%33.93’ü Maraş Biberi üretim faaliyetine ayrılmaktadır. Kahramanmaraş ve Gaziantep illerindeki Maraş Biberi ekim alanlarının aynı ve Kilis ilinden daha fazla olduğu tespit edilmiştir $(\mathrm{p}<0.10)$. İşledikleri arazide Maraş Biberi üretimine en 
fazla yer ayıran il Kilis iken, en az yer ayıran il Kahramanmaraş'tır $(p<0.05)$. Kilis, son yıllarda Maraş Biberi üretiminde en önemli illerden birisi olmuştur. Musabeyli ilçesi Hasancalı köyünde 8 tane biber fabrikası faaliyet göstermektedir. $\mathrm{Bu}$ da ildeki üreticilerin geçim kaynağının önemli bir kısmını Maraş Biberi üretim faaliyetinden sağladıklarını göstermektedir.

Çizelge 2. Anket yapılan bireylerin sosyo-demografik özellikleri

\begin{tabular}{|c|c|c|c|c|c|}
\hline $\begin{array}{l}\text { Demografik } \\
\text { özellikler }\end{array}$ & Üretici sayısı & Oran (\%) & $\begin{array}{l}\text { Demografik } \\
\text { özellikler }\end{array}$ & Üretici sayısı & Oran (\%) \\
\hline \multicolumn{3}{|l|}{ Yaş (yıl) } & \multicolumn{3}{|c|}{ Tarımsal üretim tecrübesi (yıl) } \\
\hline$\leq 40$ & 50 & 32.05 & $\leq 20$ & 57 & 36.54 \\
\hline $41-55$ & 68 & 43.59 & $21-40$ & 78 & 50.00 \\
\hline$\geq 56$ & 38 & 24.36 & $\geq 41$ & 21 & 13.46 \\
\hline Toplam & 156 & 100.00 & Toplam & 156 & 100.00 \\
\hline \multicolumn{3}{|l|}{ Eğitim (yıl) } & \multicolumn{3}{|c|}{ Ailede yaşayan birey sayısı } \\
\hline$\leq 5$ & 99 & 63.46 & $1-5$ & 70 & 44.87 \\
\hline 6-8 & 35 & 22.44 & 6-7 & 58 & 37.18 \\
\hline$\leq 9$ & 22 & 14.10 & $\geq 8$ & 28 & 17.95 \\
\hline Toplam & 156 & 100.00 & Toplam & 156 & 100.00 \\
\hline \multicolumn{3}{|c|}{ Elde edilen aylık gelir (TL) } & \multicolumn{3}{|c|}{ Ailede tarımda çalışan birey sayısı } \\
\hline$\leq 1499$ & 51 & 32.69 & 1 & 54 & 34.62 \\
\hline $1500-2500$ & 75 & 48.08 & $2-3$ & 59 & 37.82 \\
\hline$\leq 2501$ & 30 & 19.23 & $\geq 4$ & 43 & 27.56 \\
\hline Toplam & 156 & 100.00 & Toplam & 156 & 100.00 \\
\hline \multicolumn{3}{|c|}{ Sosyal güvence } & \multicolumn{3}{|c|}{ Tarım dışı geliri olma durumu } \\
\hline Var & 145 & 92.95 & Evet & $\begin{array}{r}67 \\
\end{array}$ & 42.95 \\
\hline Yok & 11 & 7.05 & Hayır & 89 & 57.05 \\
\hline Toplam & 156 & 100.00 & Toplam & 156 & 100.00 \\
\hline
\end{tabular}

Çizelge 3. İllerdeki Maraş Biberi ekili alanın oransal dağılımı (\%)

\begin{tabular}{|l|c|c|c|}
\hline & $\begin{array}{c}\text { Ortalama Maraş Biberi ekim } \\
\text { alanı genişliği (da)** }\end{array}$ & $\begin{array}{c}\text { Ortalama işletme arazi } \\
\text { genişliği (da)* }\end{array}$ & $\begin{array}{c}\text { Ortalama işletme arazisi } \\
\text { içerisinde Maraş Biberi üretim } \\
\text { alanının payı (\%)* }\end{array}$ \\
\hline Gaziantep & $46.71^{\mathrm{a}}$ & $152.83^{\mathrm{a}}$ & $30.56^{\mathrm{a}}$ \\
\hline Kahramanmaraş & $45.39^{\mathrm{a}}$ & $169.42^{\mathrm{a}}$ & $26.79^{\mathrm{a}}$ \\
\hline Kilis & $34.73^{\mathrm{b}}$ & $77.77^{\mathrm{b}}$ & $44.65^{\mathrm{b}}$ \\
\hline Genel & 40.88 & 120.47 & 33.93 \\
\hline
\end{tabular}

One-Way ANOVA testi sonucuna göre iller arasındaki fark *p<0.10, ${ }^{* *} \mathrm{p}<0.01$ için anlamlıdır.

LSD testine göre gruplar arasındaki fark p<0.05 için anlamlıdır, ortalamaları farklı olanlar değişik harfle gösterilmiştir

Üretici Memnuniyetinin Yapısal Eşitlik Modeli ile Belirlenmesi

Maraş Biberi üretim memnuniyeti üzerinde etkili olduğu düşünülen gizil değişkenlere ait gözlenen değişkenlerin analizinde 5’li likert ölçeği kullanılmıştır. Değerlendirme dereceleri aşağıdaki gibidir.

- Kesinlikle katılmıyorum, 1

- $\quad$ Biraz katıliyorum, 2

- $\quad$ Orta derecede katılıyorum, 3

- Oldukça katılıyorum, 4

- Kesinlikle katıllyorum, 5’i temsil etmektedir.

Gözlenen 39 değişkenin güvenilirlik analizi sonucuna göre memnuniyet ölçeğinin güvenilir olduğu $(\alpha=0.795)$ ve soruların ortalamalarının birbirinden farklı olduğu tespit edilmiştir (Hotelling's T2=9127.694; $\mathrm{p}<0.01$ ). Bu sonuçlara göre, değişkenler diğer analizlerde güvenle kullanılabilir.

Üreticilerin 'Maraş Biberi üretiminden memnunum' önermesine katılım ortalaması 3.13 olarak tespit edilmiştir. $\mathrm{Bu}$ önerme Maraş Biberi üretim memnuniyeti gözlenen değişkenini temsil etmektedir.

Maraş Biberi Üretim Memnuniyetinin Doğrulayıcı Faktör Analizi ile Belirlenmesi

Üreticilerin Maraş Biberi üretim memnuniyeti belirlemek amacıyla toplam 39 önermeye verdiği 
yanıtlar değerlendirilmiştir. Güvenilirlik analizi yapıldıktan sonra likert verilere AMOS programında doğrulayıcı faktör analizi (ikinci düzey çok faktörlü model) uygulanmış 16 değişkenin YEM analizinde kullanılmasına karar verilmiştir. YEM analizinde kullanılacak gizil ve gözlenen değişkenler Çizelge 4'te verilmişstir.

Çizelge 4. YEM analizinde kullanılan gizil ve gözlenen değişkenler

\begin{tabular}{|c|c|c|c|c|c|}
\hline Kod & Önermeler & Min. & Max. & Ort. & Std. Spm. \\
\hline \multicolumn{6}{|c|}{ Ekonomik faktörler } \\
\hline $\mathrm{c} 235$ & Maraş Biberi üretiminde fazla işgücü gerekmez & 1 & 3 & 1.39 & 0.607 \\
\hline $\mathrm{c} 236$ & Maraş Biberi üretiminde yabancı işgücüne ihtiyaç duymam. & 1 & 3 & 1.40 & 0.609 \\
\hline $\mathrm{c} 238$ & Maraş Biberi üretim masrafları düşüktür & 1 & 3 & 1.90 & 0.833 \\
\hline \multicolumn{6}{|c|}{ Çevresel ve fiziksel faktörler } \\
\hline $\mathrm{c} 246$ & Ürünün yetiştirme süresi uygundur & 3 & 5 & 4.76 & 0.483 \\
\hline $\mathrm{c} 247$ & Maraş Biberi üretimi için iklim koşulları elveriş̧lidir & 4 & 5 & 4.82 & 0.385 \\
\hline c249 & Yörede bu ürün kaliteli yetiştirilmektedir & 3 & 5 & 4.79 & 0.468 \\
\hline \multicolumn{6}{|c|}{ Kişisel faktörler } \\
\hline $\mathrm{c} 251$ & Yetiştirme tekniği hakkında geçmişten gelen tecrübem var & 3 & 5 & 4.56 & 0.644 \\
\hline $\mathrm{c} 252$ & $\begin{array}{l}\text { Bu ürünü yetiştirmeye karar verirken aile üyelerinden fikir } \\
\text { alırım }\end{array}$ & 2 & 5 & 4.14 & 0.933 \\
\hline $\mathrm{c} 253$ & $\begin{array}{l}\text { Bu ürünü yetiştirmeye karar verirken diğer çiftçilerden fikir } \\
\text { alırım }\end{array}$ & 3 & 5 & 4.28 & 0.841 \\
\hline \multicolumn{6}{|c|}{ Pazarlama faktörleri } \\
\hline $\mathrm{c} 257$ & Ürün bedelinin geç ödenmemektedir & 1 & 5 & 3.31 & 1.371 \\
\hline c259 & Kolay alıcı bulurum & 3 & 5 & 4.38 & 0.782 \\
\hline $\mathrm{c} 262$ & Pazarlamada sıkıntı yaşamam & 3 & 5 & 4.01 & 0.887 \\
\hline c266 & Kısa süre içinde ürünü paraya çevirebilirim & 3 & 5 & 4.45 & 0.721 \\
\hline \multicolumn{6}{|c|}{ Maraş Biberi üretim öngörüsü } \\
\hline c269 & Ürüne göre ekipmanlarımı geliştireceğim & 2 & 5 & 4.23 & 0.908 \\
\hline $\mathrm{c} 270$ & Gelecekte üretim desenindeki payını artıracağım & 2 & 5 & 4.29 & 0.873 \\
\hline $\mathrm{c} 272$ & Sağlam bir ürün sorun yaşamıyorum & 3 & 5 & 4.65 & 0.660 \\
\hline
\end{tabular}

1:Kesinlikle Katılmıyorum, 2:Az Katılıyorum, 3:Orta Derecede Katılıyorum, 4:Oldukça Katılıyorum, 5:Kesinlikle Katılıyorum

Maraş Biberi Üretim Memnuniyetinin Yol Analizi ile Belirlenmesi

Yol analizi, DFA ile yapılan düzenlemeler ve iyileştirmeler sonucunda modeldeki değişkenlerin arasında oluş̧urulan yolların anlamlılı̆̆ını ölçek için kullanılan bir metottur. Yol analizi ile modelin test edilmesi, gerekli modifikasyonların yapılması ve tekrar modelin test edilmesi gerekmektedir (Meydan ve Şeşen, 2011).

Modelin geçerliliğine ilişkin uyum kriterleri değerlendirildikten sonra, regresyon katsayılarına ilişkin değerler Çizelge 5’te verilmiştir.

Standardize edilmemiş regresyon katsayıları hesaplanırken, her bir gizil değişkeni ölçmede kullanılan gösterge değişkenlerden biri tesadüfi olarak "1" değeri alır. Bu değer dikkate alınarak diğer gösterge değişkenlerinin gösterge yükleri hesaplanır ve daha sonra bu değerler standart hale getirilir.
Ekonomik, çevresel ve fiziksel, kişisel, pazarlama faktörleri ve üretim öngörüsü gizil değişkenleri ile gözlenen değişkenler arasındaki ilişkiyi ölçmek amacıyla gözlenen değişkenlerden bir tanesi 1 olarak tanımlanmış diğer değişkenler bu değişkene göre hesaplanmıştır. Tüm gözlenen değişkenlerin regresyon katsayılarına ait değerler istatistiki açıdan anlamlı bulunmuştur $(\mathrm{p}<0.01)$.

Çizelge 5 incelendiğinde tasarlanan modele yönelik araştırılan 9 hipotezden 6 tanesi kabul edilmiş, 3 tanesi de reddedilmiştir. Hipotezlerin kabul edilme durumları Çizelge 6'da gösterilmiştir. $\mathrm{H}_{1}, \mathrm{H}_{3}, \mathrm{H}_{4}, \mathrm{H}_{5}$, $\mathrm{H}_{6}, \mathrm{H}_{8}$ Hipotezleri kabul edilmiş, $\mathrm{H}_{2}, \mathrm{H}_{7}, \mathrm{H}_{9}$ hipotezleri reddedilmiştir.

Tüm hipotezlere ait Path analizi sonuçları Şekil 2'de gösterilmiştir. Ancak anlamsız olan hipotezlere ait yolların modelin uyum iyiliğini etkileyeceği düşünüldüğünden silinmesi ve modelin tekrar test edilmesi gerekmektedir. 
Analizin diğer aşamasında anlamlı olmayan çevresel ve fiziksel faktörler $\rightarrow$ üretim öngörüsü, pazarlama faktörleri $\rightarrow$ üretim öngörüsü ve çevresel ve fiziksel faktörler $\rightarrow$ üretim memnuniyeti yolları modelden çıkarılarak yeniden bir analiz yapılmıştır.
Modelden çıkarılan anlamsız yollardan sonra model yeniden test edilmiş (Şekil 3) ve gizil değişkenlerin anlamlılık düzeylerinde değişiklik gözlemlenmiştir. Anlamlı olan kişisel faktörler $\rightarrow$ üretim memnuniyeti yolu anlamsız çıkmış, bu yol da modelden çıkarılmıştır (Çizelge 7). Model en son Şekil 3’teki halini almıştır.

Çizelge 5. Standardize edilmemiş regresyon katsayıları (Modelin ilk hali)

\begin{tabular}{|l|l|l|c|c|c|c|}
\hline Değişkenler & Etki & Değişkenler & Tahmin & Standart hata & t değeri & P değeri \\
\hline uretimongoru & $<---$ & Ekonomik & 0.129 & 0.054 & 2.392 & 0.017 \\
\hline uretimongoru & $<---$ & kisisel & 0.085 & 0.035 & 2.395 & 0.017 \\
\hline uretimongoru & $<---$ & cevreselvefiziksel & 0.123 & 0.094 & 1.315 & 0.189 \\
\hline uretimongoru & $<---$ & pazarlama & 0.026 & 0.026 & 0.991 & 0.322 \\
\hline memnuniyet2 & $<---$ & uretimongoru & 0.646 & 0.156 & 4.142 & 0.000 \\
\hline memnuniyet2 & $<---$ & ekonomik & 0.660 & 0.092 & 7.138 & 0.000 \\
\hline memnuniyet2 & $<---$ & cevreselvefiziksel & 0.129 & 0.107 & 1.208 & 0.227 \\
\hline memnuniyet2 & $<---$ & pazarlama & 0.094 & 0.031 & 2.984 & 0.003 \\
\hline memnuniyet2 & $<---$ & kisisel & -0.070 & 0.037 & -1.910 & 0.056 \\
\hline c238 & $<---$ & ekonomik & 1.000 & & & \\
\hline c236 & $<---$ & ekonomik & 1.203 & 0.142 & 8.465 & 0.000 \\
\hline c235 & $<---$ & ekonomik & 1.226 & 0.144 & 8.521 & 0.000 \\
\hline c249 & $<---$ & cevreselvefiziksel & 0.957 & 0.164 & 5.848 & 0.000 \\
\hline c247 & $<---$ & cevreselvefiziksel & 1,000 & & & \\
\hline c246 & $<---$ & cevreselvefiziksel & 1.240 & 0.192 & 6.445 & 0.000 \\
\hline c253 & $<---$ & kisisel & 1.000 & & & \\
\hline c252 & $<---$ & kisisel & 1.011 & 0.112 & 8.997 & 0.000 \\
\hline c251 & $<---$ & kisisel & 0.471 & 0.071 & 6.604 & 0.000 \\
\hline c266 & $<--$ & pazarlama & 0.449 & 0.079 & 5.706 & 0.000 \\
\hline c262 & $<---$ & pazarlama & 0.550 & 0.097 & 5.686 & 0.000 \\
\hline c259 & $<---$ & pazarlama & 0.549 & 0.089 & 6.146 & 0.000 \\
\hline c257 & $<--$ & pazarlama & 1.000 & & & \\
\hline c272 & $<---$ & uretimongoru & 1.000 & & & \\
\hline c270 & $<--$ & uretimongoru & 3.440 & 0.751 & 4.581 & 0.000 \\
\hline c269 & $<--$ & uretimongoru & 2.198 & 0.473 & 4.651 & 0.000 \\
\hline
\end{tabular}

Çizelge 6. Araştırma hipotezlerinin kabul edilme durumu

\begin{tabular}{|l|c|}
\hline Hipotezler & $\begin{array}{c}\text { Kabul } \\
\text { durumu }\end{array}$ \\
\hline H1: Ekonomik faktörler Maraş Biberi üretim memnuniyeti üzerinde doğrudan etkilidir. & Kabul \\
\hline H2: Çevresel ve fiziksel faktörler Maraş Biberi üretim memnuniyeti üzerinde doğrudan etkilidir. & Red \\
\hline H3: Kişisel faktörler Maraş Biberi üretim memnuniyeti üzerinde doğrudan etkilidir. & Kabul \\
\hline H4: Pazarlama faktörleri Maraş Biberi üretim memnuniyeti üzerinde doğrudan etkilidir. & Kabul \\
\hline H5: Maraş Biberi üretim öngörüsüretim memnuniyeti üzerinde doğrudan etkilidir. & Kabul \\
\hline H6: Ekonomik faktörler Maraş Biberi üretim öngörüsünde doğrudan etkilidir. & Kabul \\
\hline H7: Çevresel ve fiziksel faktörler Maraş Biberi üretim öngörüsünde üzerinde doğrudan etkilidir. & Red \\
\hline H8: Kişisel faktörler Maraş Biberi üretim öngörüsünde doğrudan etkilidir. & Kabul \\
\hline H9: Pazarlama faktörleri Maraş Biberi üretim öngörüsünde doğrudan etkilidir. & Red \\
\hline
\end{tabular}




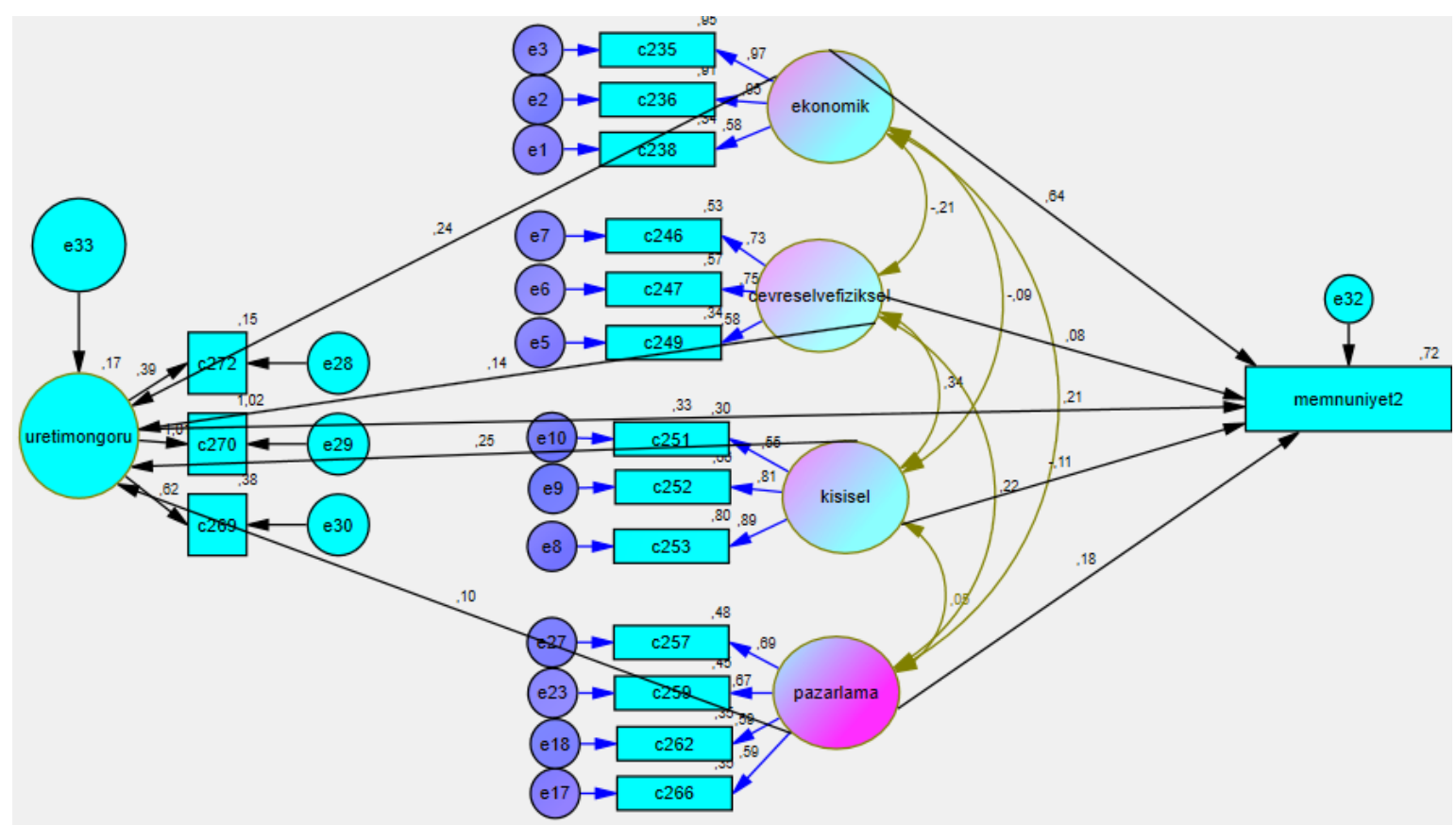

Şekil 2. Maraş Biberi üretim memnuniyeti YEM model sonucu 1

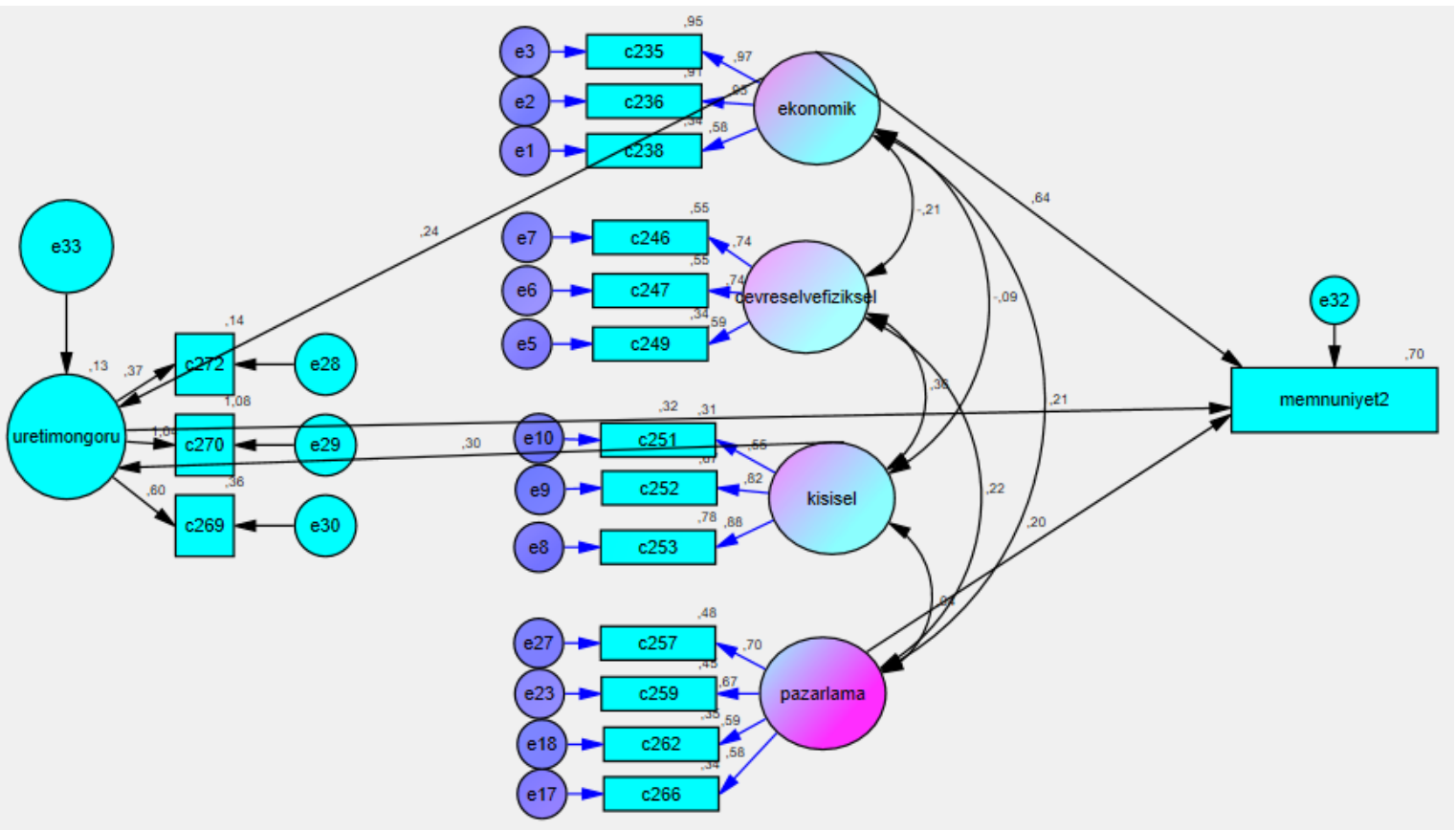

Şekil 3. Maraş Biberi üretim memnuniyeti YEM sonucu 2

Modelin ilk haline ek olarak $\mathrm{H}_{8}$ hipotezi de reddedilmiştir. Dolayısı ile tasarlanan 9 hipotezden 4 tanesi reddedilmiş, 5 tanesi kabul edilmiştir (Çizelge 8).

Başlangıç uyum indeksi olarak kabul edilen ki-kare istatistiği, test sonucunda \%1 anlamlllık düzeyinde istatistiki açıdan anlamlı bulunmuştur $(p<0.01)$ YEM'de ki-kare değerinin anlamlı olmaması beklenmektedir. Serbestlik derecesinin büyük olduğu bazı durumlarda ki- kare değeri anlamlı çıkabilmektedir. Ki-kare değeri örnek büyüklüğüne çok duyarlı olduğundan bu durumda ki-karenin tek başına anlamlı olup olmamasından ziyade $x^{2 / s d}$ değerine bakılır. Bu değerin 3'ten küçük olması kikare sonucu anlamlı bile olsa modelin genel uyumunun yeterli olduğunu gösterir $\left(x^{2} / \mathrm{sd}<3\right)$. Modelin son haline ilişkin diğer uyum değerleri modelin yeterli uyum sağladığını göstermektedir (NNFI=0.90, RMSEA $=0.06$, RMR=0.04, IFI=0.90, CFI=0.90) (Çizelge 9). 
Çizelge 7. Standardize edilmemiş regresyon katsayıları modelin son hali

\begin{tabular}{|c|c|c|c|c|c|c|}
\hline Değişkenler & Etki & Değişkenler & Tahmin & Standart hata & t değeri & $\mathrm{P}$ değeri \\
\hline uretimongoru & $<---$ & ekonomik & 0.121 & 0.049 & 2.470 & 0.014 \\
\hline uretimongoru & $<---$ & kisisel & 0.099 & 0.035 & 2.809 & 0.005 \\
\hline memnuniyet2 & $<---$ & uretimongoru & 0.629 & 0.151 & 4.178 & 0.000 \\
\hline memnuniyet2 & $<---$ & ekonomik & 0.653 & 0.090 & 7.280 & 0.000 \\
\hline memnuniyet2 & $<---$ & pazarlama & 0.102 & 0.030 & 3.406 & 0.000 \\
\hline $\mathrm{c} 238$ & $<--$ & ekonomik & 1.000 & & & \\
\hline $\mathrm{c} 236$ & $<<--$ & ekonomik & 1.202 & 0.142 & 8.487 & 0.000 \\
\hline $\mathrm{c} 235$ & $<<---$ & ekonomik & 1.223 & 0.143 & 8.536 & 0.000 \\
\hline c249 & $<---$ & cevreselvefiziksel & 0.978 & 0.168 & 5.831 & 0.000 \\
\hline $\mathrm{c} 247$ & $<--$ & cevreselvefiziksel & 1.000 & & & \\
\hline $\mathrm{c} 246$ & $<--$ & cevreselvefiziksel & 1.277 & 0.201 & 6.358 & 0.000 \\
\hline $\mathrm{c} 253$ & $<--$ & kisisel & 1.000 & & & \\
\hline $\mathrm{c} 252$ & $<---$ & kisisel & 1.031 & 0.114 & 9.017 & 0.000 \\
\hline $\mathrm{c} 251$ & $<---$ & kisisel & 0.479 & 0.072 & 6.650 & 0.000 \\
\hline c266 & $<---$ & pazarlama & 0.440 & 0.078 & 5.641 & 0.000 \\
\hline c262 & $<---$ & pazarlama & 0.550 & 0.096 & 5.705 & 0.000 \\
\hline c259 & $<---$ & pazarlama & 0.550 & 0.089 & 6.170 & 0.000 \\
\hline c257 & $<---$ & pazarlama & 1.000 & & & \\
\hline c272 & $<---$ & uretimongoru & 1.000 & & & \\
\hline $\mathrm{c} 270$ & $<---$ & uretimongoru & 3.673 & 0.832 & 4.415 & 0.000 \\
\hline c269 & $<---$ & uretimongoru & 2.210 & 0.481 & 4.593 & 0.000 \\
\hline
\end{tabular}

Çizelge 8. Araştırma hipotezlerinin kabul edilme durumu (son hali)

\begin{tabular}{|l|c|}
\hline Hipotezler & $\begin{array}{c}\text { Kabul } \\
\text { durumu }\end{array}$ \\
\hline $\mathrm{H}_{1}:$ Ekonomik faktörler Maraş Biberi üretim memnuniyeti üzerinde doğrudan etkilidir. & Kabul \\
\hline $\mathrm{H}_{2}:$ Çevresel ve fiziksel faktörler Maraş Biberi üretim memnuniyeti üzerinde doğrudan etkilidir. & Red \\
\hline $\mathrm{H}_{3}:$ Kişisel faktörler Maraş Biberi üretim memnuniyeti üzerinde doğrudan etkilidir. & Kabul \\
\hline $\mathrm{H}_{4}:$ Pazarlama faktörleri Maraş Biberi üretim memnuniyeti üzerinde doğrudan etkilidir. & Kabul \\
\hline $\mathrm{H}_{5}:$ Maraş Biberi üretim öngörüsü üretim memnuniyeti üzerinde doğrudan etkilidir. & Kabul \\
\hline $\mathrm{H}_{6}:$ Ekonomik faktörler Maraş Biberi üretim öngörüsünde doğrudan etkilidir. & Kabul \\
\hline $\mathrm{H}_{7}:$ Cevresel ve fiziksel faktörler Maraş Biberi üretim öngörüsünde üzerinde doğrudan etkilidir. & Red \\
\hline $\mathrm{H}_{8}:$ Kişisel faktörler Maraş Biberi üretim öngörüsünde doğrudan etkilidir. & Red \\
\hline $\mathrm{H}_{9}:$ Pazarlama faktörleri Maraş Biberi üretim öngörüsünde doğrudan etkilidir. & Red \\
\hline
\end{tabular}

Çizelge 9. Model uyum değerleri

\begin{tabular}{|l|c|c|}
\hline & Uyum değeri & Uyum kriteri \\
\hline $\mathrm{X}^{2}$ değeri (CMIN) & 238.475 & \\
\hline $\mathrm{p}$ & 0.000 & \\
\hline $\mathrm{sd}$ & 108 & İyi Uyum \\
\hline $\mathrm{X}$ 2/sd & 2.21 & İyi uyum \\
\hline NNFI (TLI) & 0.90 & Iyi Uyum \\
\hline RMSEA & 0.08 & Iyi Uyum \\
\hline RMR & 0.05 & Kabul Edilebilir Uyum \\
\hline IFI & 0.90 & Kabul Edilebilir Uyum \\
\hline CFI & 0.90 & \\
\hline
\end{tabular}

$\mathrm{Y}_{1}($ memnuniyet $)=0.64 *$ ekonomik fakt.+ $0.32 *$ üretim öngörüsü +0.20 pazarlama fakt.
$(0.000)$
$(0.000)$
(0.000)

$\mathrm{Y}_{2}$ (üretim öngörüsü) $=0.24^{*}$ ekonomik faktörler $+0.30^{*}$ kişisel faktörler
$(0.000)$
(0.000)

Üreticilerin Maraş Biberi üretim memnuniyetine ve üretim öngörüsüne ait gizil değişkenler arasındaki ilişki yukarıdaki fonksiyonda gösterilmiştir. Üretim memnuniyetinde en etkili gizil değişkenler sırasıyla 
ekonomik faktörler ve üretim öngörüsü gizil değişkenleridir, pazarlama faktörleri gizil değişkeni ise en az etkili gizil değişkendir.

Üretim öngörüsünde etkili olan ekonomik ve kişisel faktörler gizil değişkenlerinin katsayıları birbirine çok yakındır.

Şekil 3’te de görüleceği gibi ekonomik faktörler $\rightarrow$ üretim memnuniyeti arasındaki ilişki katsayısı 0.64, üretim öngörüsü $\rightarrow$ üretim memnuniyeti arasındaki ilişki katsayısı 0.32, pazarlama faktörleri $\rightarrow$ üretim memnuniyeti arasındaki ilişki katsayısı ise 0.20 olarak tahmin edilmiştir.

Ekonomik faktörler gizil değişkenindeki bir birimlik artış Maraş Biberi üretim memnuniyetini 0.64'lük bir artışla, üretim öngörüsü gizil değişkenindeki bir birimlik artış Maraş Biberi üretim memnuniyetini 0.32'lik bir artışla, pazarlama faktörleri gizil değişkenindeki bir birimlik artış Maraş Biberi üretim memnuniyetini 0.20 'lik bir artışla etkileyecektir (Çizelge 10)

Çizelge 10. Memnuniyet yapısal model sonuçları (gizil değişkenler)

\begin{tabular}{|l|c|c|}
\hline & Path katsayısı & $\mathrm{t}$ değeri \\
\hline Ekonomik faktörler & 0.643 & 7.280 \\
\hline Üretim öngörüsü & 0.316 & 4.178 \\
\hline Pazarlama faktörleri & 0.198 & 3.406 \\
\hline
\end{tabular}

Ekonomik faktörler gizil değişkenindeki bir birimlik artış Maraş Biberi üretim öngörüsünü 0.24'lük bir artışla, kişisel faktörler gizil değişkenindeki bir Çizelge 12. Ekonomik faktörlere ait gözlenen değişkenlerin path katsayıları

\begin{tabular}{|l|l|c|}
\hline Kod & Önermeler & Path katsayıları \\
\hline c235 & Maraş Biberi üretiminde fazla işgücü gerekmez & 0.973 \\
\hline c236 & Maraş Biberi üretiminde yabancı işgücüne ihtiyaç duymam & 0.954 \\
\hline c238 & Maraş Biberi üretim masrafları düşüktür & 0.580 \\
\hline
\end{tabular}

Üretim öngörüsü 3 adet gözlenebilen değişkenle ifade edilmiş bütün değişkenler istatistiki açıdan anlamlı ve path katsayıları pozitif çıkmıştır. Bu sonuçlara göre üretim öngörüsü üzerinde etkisi sırasıyla en yüksek olan 'Gelecekte üretim desenindeki payını artıracağım' (1.038) önermesi ve 'Ürüne göre ekipmanlarımı birimlik artış Maraş Biberi üretim öngörüsünü 0.30 'luk bir artışla etkileyecektir

(Çizelge 11).

Çizelge 11. Üretim öngörüsü yapısal model sonuçları (gizil değişkenler)

\begin{tabular}{|l|c|c|}
\hline & Path katsayısı & t değeri \\
\hline Ekonomik faktörler & 0.237 & 2.470 \\
\hline Kişisel faktörler & 0.300 & 2.809 \\
\hline
\end{tabular}

Ekonomik faktörler gizil değişkeni üretim memnuniyeti ve üretim öngörüsü üzerinde etkilidir. $\mathrm{Bu}$ faktör, 3 gözlenebilir değişkenle ifade edilmiştir. Bütün gözlenebilir değişkenler istatistiki açıdan anlamlı bulunmuştur. Üç değişken de pozitif katsayıya sahiptir. En yüksek katsayıya sahip gözlenen değişken 'Maraş Biberi üretimi fazla işgücü gerektirmez' (0.973) değişkenidir. 'Maraş Biberi üretimi fazla işgücü gerektirmez' önermesine katılım düzeyi arttıkça Maraş Biberi üretim memnuniyeti de artacaktır. İkinci önemli değişken, 'Maraş Biberi üretiminde yabanc1 işgücüne ihtiyaç duymam' (0.954) önermesidir. Üreticilerin en önemli sorunlarından biri yabancı işgücü bulma güçlüguüdür. 'Yabancı işgücüne ihtiyaç duymam' önermesine katılım düzeyi arttıkça üreticilerin Maraş Biberi üretim memnuniyeti artacaktır. Diğer bir önemli değişken ise 'Maraş Biberi üretim masrafları düşüktür' (0.580) önermesidir. Bu önermeye de katılım düzeyi arttıkça üretim memnuniyeti de artacaktır (Çizelge 12). geliştireceğim' önermesidir (0.600). Bu önermelere katılım düzeyi arttıkça Maraş Biberi üretim memnuniyeti artacaktır. 'Sağlam bir ürün sorun yaşamiyorum' (0.373) gözlenen değişkeni ise üretim memnuniyeti üzerinde diğer değişkenlere göre daha az etkilidir (Çizelge 13)

Çizelge 13. Maraş Biberi üretim öngörüsüne ait gözlenen değişkenlerin path katsayıları

\begin{tabular}{|l|l|c|}
\hline Kod & Önermeler & Path katsayıs \\
\hline c269 & Ürüne göre ekipmanlarımı geliştireceğim & 0.600 \\
\hline c270 & Gelecekte üretim desenindeki payını artıracağım & 1.038 \\
\hline c272 & Sağlam bir ürün sorun yaşamıyorum & 0.373 \\
\hline
\end{tabular}

Üretim memnuniyeti üzerinde etkili olan pazarlama faktörleri 4 adet gözlenen değişkenle ifade edilmiştir. Tüm değişkenler istatistiki açıdan anlamlı ve pozitif katsayıya sahiptir. 'Ürün bedeli geç ödenmemektedir' (0.695) ve 'Kolay alıcı bulurum' (0.671) önermeleri 
içerisinde ürünü paraya çevirebilirim' (0.581) önermeleridir. $\mathrm{Bu}$ önermelerin daha az etkili çıkması üreticilerin bu konuda sıkıntı yaşamamalarından kaynaklanabilir (Çizelge 14).

Çizelge 14. Pazarlama faktörlerine ait gözlenen değişkenlerin path katsayıları

\begin{tabular}{|l|l|c|}
\hline Kod & Önermeler & Path katsayısı \\
\hline c257 & Ürün bedeli geç ödenmemektedir & 0.695 \\
\hline c259 & Kolay alıcı bulurum & 0.671 \\
\hline c262 & Pazarlamada sıkıntı yaşamam & 0.590 \\
\hline c266 & Kısa süre içinde ürünü paraya çevirebilirim & 0.581 \\
\hline
\end{tabular}

Üretim öngörüsü üzerinde etkili olan kişisel faktörler gizil değişkeni 3 adet gözlenebilir değişkenler ifade edilmiş ve değişkenlere ait katsayılar istatistiki açıdan anlamlı ve pozitif katsayıya sahiptir. En etkili gözlenen değişken 'Bu ürünü yetiştirmeye karar verirken diğer çiftçilerden fikir alırım' (0.884) iken bunu 'Bu ürünü yetiştirmeye karar verirken aile üyelerinden fikir alırım' (0.821) değişkeni takip etmektedir. $\mathrm{Bu}$ önermelere katılım düzeyi arttıkça Maraş Biberi üretim memnuniyeti de artacaktır. 'Yetiştirme tekniği hakkında geçmişten gelen tecrübem var' (0.553) değişkeni diğerlerine göre daha az etkili değişkendir (Çizelge 15)

Çizelge 15. Kişisel faktörlere ait gözlenen değişkenlerin path katsayıları

\begin{tabular}{|l|l|c|}
\hline Kod & Önermeler & Path katsayss \\
\hline c251 & Yetiştirme tekniği hakkında geçmişten gelen tecrübem var & 0.553 \\
\hline c252 & Bu ürünü yetiştirmeye karar verirken aile üyelerinden fikir alırım & 0.821 \\
\hline c253 & Bu ürünü yetiştirmeye karar verirken diğer çiftçilerden fikir alırım & 0.884 \\
\hline
\end{tabular}

\section{SONUÇ ve ÖNERILLER}

Üreticilerin Maraş Biberi üretim memnuniyeti belirlemek amacıyla yapılan bu çalışmada Yapısal Eşitlik Modeli sonucuna göre ekonomik faktörler, üretim öngörüsü ve pazarlama faktörlerinin Maraş Biberi üretim memnuniyeti üzerinde etkili faktörler olduğu görülmektedir. Çevresel-fiziksel faktörlerin ve kişisel faktörlerin istatistiki açıdan anlamsız çıkması üreticilerin bu faktörler açısından herhangi bir sorun ile karşılaşmadıklarının bir göstergesi olabilir. Kolay hasat edilebilir çeşitlerin geliştirilmesi ve makineli hasat ile birlikte ekonomik sorunlar olan yabanc1 işgücü temini ve üretimde fazla işgücü kullanımının önüne geçilerek memnuniyet artırılabilir. Yine aynı şekilde ürünlerini özellikle toptancıya pazarlayan üreticilerin ürün bedellerini erken alması ve kolay alıcı bulması ile üretim memnuniyeti artacak hatta üreticiler gelecekte Maraş Biberi’nin üretim desenindeki payını artıracaklardır.

Maraş Biberi üretim memnuniyeti üzerinde en etkili gizil değişken ekonomik faktörlerdir. Ekonomik faktöre ait gözlenen değişkenlere katılım düzeyi arttıkça üretim memnuniyeti de artacaktır. Maraş Biberi üretiminde en önemli ekonomik sorunlar işgücü temininde yaşanan zorluklar ve üretimde fazla işgücünün kullanılmasıdır. Bu sorunlara kolay hasat edilebilir çeşitlerin geliştirilmesi ve makineli hasat çözüm olabilir. Bu önerinin gerçekleşmesi ile birlikte bir diğer önemli ekonomik sorun olan üretim masraflarının da azalmasına katkı sağlanabilir.

Bunun yanı sıra Maraş Biberi denildiğinde genel algı bu ürünün Kahramanmaraş ilinde üretildiğidir. Oysa Maraş Biberi yoğun olarak Gaziantep ve Kilis illerinde de üretilmektedir. Hatta Gaziantep ve Kilis illerindeki üreticilerin, Kahramanmaraş ilinden daha çok ekili alanda biber tarımı yaptıkları görülmektedir. Kahramanmaraş ili Coğrafi işaretli ürünü olan Maraş Biberi’nde öncü il olması rağmen üretimin, diğer illere göre daha az olması il için önemli bir eksikliktir. Coğrafi işaret tescili Kahramanmaraş ilinden alınmasına rağmen coğrafi işaret tescili alan firma sayısı oldukça azdır. Bu konuda yapılacak tanıtım ve reklamlarla firmaların coğrafi işaret tescili almaya özendirilmesi gerekmektedir. Coğrafi işaret, hem firmalar için kar avantajı sağlarken hem de ürünün standartlara uygun, daha kaliteli ve daha güvenilir olduğu belgelendiren bir sertifikadır. Coğrafi işaret tescili, bölge ve ülke ekonomisine önemli katkılar sağlayacaktır. Bunun yanı sıra Gaziantep ve Kilis illerinde üretilen biberler Maraş Biberi tohumu kullanılarak üretilmesine rağmen Gaziantep biberi, Kilis biberi ifadelerinin kullanıldığ çekmektedir. Biber üretilen ilin adını almaktadır. Bu, diğer illerdeki satışlarda Maraş Biberi'nin tanıtımını engellemektedir. Tüketicilere yapılacak reklam ve tanitımlar Maraş Biberi'nin Coğrafi işaretli bir ürün olduğu anlatılmalı ve logolu ürünleri tercih etmeleri sağlanmalıdır. Maraş Biberi, ülke ve dünya genelinde en az Maraş Dondurması kadar tanınır bir ürün olmalıdır. Üreticiler, sektör temsilcileri, akademisyenler ve diğer paydaşların bir araya gelerek hazırlayacakları Maraş Biberi eylem planı ile üretimdeki fırsatlar, tehditler, güçlü ve zayıf yönler 
tespit edilerek Maraş Biberi sürdürülebilirliğine önemli katkı sağlanabilir.

\section{TEŞEKKÜR}

Bu makale Kahramanmaraş Sütçü İmam Üniversitesi, Bilimsel Araştırma Projeleri Koordinasyon Birimi tarafindan desteklenen 2017/1-75D proje No'lu Maraş Biberi'nin Ekonomik Analizi ve Üretici Memnuniyeti adlı doktora tezinden türetilmişstir. Katkılarından dolayı teşekkür ederiz.

\section{KAYNAKLAR}

Akbay C, Boz İ, Tiryaki GY, Candemir S., Arpacı BB 2012. Kahramanmaraş ve Gaziantep İllerinde Kırmızıbiberin Üretim Yapısı ve Kurutma Yöntemleri. KSÜ Doğa Bilimleri Dergisi, 15(2): 110.

Anonim 2016. Gıda Tarım ve Hayvancılık İlçe Müdürlükleri Çiftçi Kayıt Sistemi Verileri (Erişim tarihi: 25.10.2016).

Avcılar MY, Varinli İ 2013. Perakende Marka Değerinin Ölçümü ve Yapısal Eşitlik Modeli Uygulaması. Detay Yayıncılık, ISBN: 978-6055216-70-2, Ankara, 203s.

Bagozzi RP 1981. Evaluating Structural Equation Models with Unobservable Variables and Measurement Error: A Comment, Journal of Marketing Research, 18(3): 375-381.

Bayram N 2013. Yapısal Eşitlik Modellemesine Giriş AMOS Uygulamaları. Ezgi Kitabevi, 2. Baskı, 162s.

Boz İ 2013. Doğu Akdeniz Bölgesi’nde Süt Sığırcılığı Yapan İşletmelerin Yapısı, Sorunları ve Çözüm Önerileri. KSÜ Doğa Bilimleri Dergisi, 16(1): 24-32.

Byrne BN 1998. Structural Equation Modeling with LISREL, PRELIS and SIMPLIS: Basic Concepts, Apllications and Programming. New Jersey: Lawrence Erlbaum Associates.

Byrne BN 2010. Structural Equation Modeling with AMOS. Newyork: Routledge.

Churchill G 1979. A Paradigm For Developing Better Measures of Marketing Constructs. Journal of Marketing Research, 16(1): 66-73.

FAO 2013. Kuru Biber Üretimi. http://faostat3.fao.org/browse/Q/QC/E （Erişim tarihi: 15.10.2016).

Gerbing DW, Anderson JC 1988. An Updated Paradigm Scale of Development Incorporating Unidimensionality and Its Assessment. Journal of Marketing, 25(2): 186-192.

Kayacan B, Gültekin YS 2012. Yapısal Eşitlik Modellemesinin (YEM) Ormancllıkta SosyoEkonomik Sorunların Çözümlenmesinde Kullanımı. III. Ormancılıkta Sosyo-Ekonomik Sorunlar Kongresi, İstanbul Üniversitesi, Orman Fakültesi 18-20 Ekim.
MacCallum RC, Austin JT 2000. Applications of Structural Equation Modeling in Psychological Research. Annual Review of Psychology, 51: 201226.

Meydan HC, Şeşen H, 2011. Yapısal Eşitlik Modellemesi AMOS Uygulamaları. Detay Yayıncılık, Ankara.

Newbold P 1995. Statistics for Business and Economics. Prentice-Hall International, New Jersey, 867pp.

Okur Berberoğlu E, Uygun S 2012. Çevre Farkındalığı-Çevre Tutumu Arasındaki İlişkinin Yapısal Eşitlik Modeli İle Sınanması. Uludağ Üniversitesi Eğitim Fakültesi Dergisi, 25(2): 459473.

Pennings JME, Leuthold RM 2000. The Role of Farmers' Behavioral Attitudes and Heterogeneity in Futures Contracts Usage. American Journal of Agricultural Economics, 82(4): 908-919.

Schumacker ER, Lomax GR 1996. A Beginner's Guide to Structural Equation Modeling. Mahwah, NJ: Erlbaum.

Seçer İ 2013. SPSS ve LISREL İle Pratik Veri Analizi, Analiz ve Raporlaştırma. AnıYayıncılık, Ankara, ISBN: 978-605-5213-28-2, 218s.

Sümer N 2000. Yapısal Eşitlik Modelleri: Temel Kavramlar ve Örnek Uygulamaları. Türk Psikoloji Yazıları 3(6): 49-74.

Şahin A, Cankurt M, Günden C, Miran, B 2008. Çiftçilerin Risk Davranışları: Bir Yapısal Eşitlik Modeli Uygulaması. Dokuz Eylül Üniversitesi İktisadi ve İdari Bilimler Fakültesi Dergisi, 23(2): 153-172.

Şimşek ÖF 2007. Yapısal Eşitlik Modellemesine Giriş Temel İlkeler ve LISREL Uygulamaları. Ankara Ekinoks Yaymları.

Tabachnick BG, Fidell LS 2001. Using Multivariate Statics. Boston: Allyn and Bacon

Terblanche NS, Boshoff C 2006. The Relationship Between A Satisfactory in-Store Shopping Experience and Retailer Loyalty. South African Journal of Business Management, 37(2): 33-43.

TÜİK 2016. Baharatlık Kırmızıbiber Üretim Bilgileri. https://biruni.tuik.gov.tr/bitki selapp/bitkisel.zul, (Erişim tarihi: 04.10.2017).

TPE 2002. Maraş Biberi. http://www.tpe.gov.tr/ turkpatentenstitusu/resources/temp/f64 65da2798f-4a44-962b-15ba8ea745d5.pdf (Erişim tarihi: 18.10.2016).

Yılmaz V, Çelik HE, Yağızer C 2009. Çevresel Duyarlılık ve Çevresel Davranışın Ekolojik Ürün Satın Alma Davranışına Etkilerinin Yapısal Eşitlik Modeliyle Araştırılması. Anadolu Üniversitesi Sosyal Bilimler Dergisi, 9(2): 1-14. 